\title{
Kristen Muhammadiyah
}

\author{
Ismail Suardi Wekke \\ Sekolah Tinggi Agama Islam Negeri (STAIN) Sorong, Papua Barat \\ Universitas Muhammadiyah Sorong, Papua Barat \\ Email: iswekke@gmail.com
}

\begin{abstract}
ABSTRAK
Artikel hanya catatan-catatan singkat terkait dengan Kristen Muhammadiyah. Tidak hanya itu juga meluas terkait Muhammadiyah di minoritas muslim, terutama di Papua Barat. Bagian utama dalam penulisan ini terkai dengan bab dalam buku Islamologi dengan penyunting Elia Tambunan \& Ahmad Fahri Yahya Ainuri.
\end{abstract}

Kata Kunci: Kristen Muhammadiyah, Minoritas Muslim, Muhammadiyah

\section{Pendahuluan}

Buku ini berjudul Islamologi, salah satu bab dalam buku tersebut "Orang Kristen Muhammadiyah" (Tambunan \& Ainuri, 2019). Buku ini berasal dari diskusi di kelas dalam perkuliahan Islamologi yang diampuh Pdt. Dr. Elia Tambunan di Sekolah Tinggi Teologi (STT) Sangkakala. Mengawali dari postingan di linimasa Pdt Elia, saya membaca bab sebagai bacaan awal terutama terkait dengan Muhammadiyah. Sekaligus menjadi pintu untuk membaca tulisan Mu'ti \& Haq (2009) yang selama ini saya hanya dengarkan saja. Karya Mu'ti \& Haq sudah terbit 10 tahun lalu dan saya belum membacanya sama sekali. Sebuah ketertinggalan memutakhirkan bacaan. Idealnya, itu tidak boleh terjadi.

\section{Muhammadiyah Kristen}

Narasi Dorce Hanggawali (h. 143-152) tentang Sekolah Muhammadiyah Waingapu memberikan gambarakan bahwa sekolah Muhammadiyah tidak khusus untuk warga muslim saja. Secara khusus Hanggawali mengemukakan "sekalipun organisasi Muhammadiyah adalah organisasi yang cukup tertutup sebelumnya tetapi mereka menerima Kristen di tengahtengahnya. Kehadiran sekolah Muhammadiyah dalam pandangan langsung seorang Kristiani menjadi informasi tangan pertama dengan kalimat "Muhammadiyah yang Kulihat".

Lembaga pendidikan Muhammadiyah menerima siswa yang menganut Protestan \& Katolik. Mu’ti \& Haq (2009) menggambarkan di tiga lokasi, Kupang (Nusa Tenggara Timur), Serui (Papua), dan Putussibau (Kalimantan Barat). Di tiga sekolah Muhammadiyah yang menjadi penelitian tersebut semuanya menerima mahasiswa yang bukan hanya muslim. Gambaran itu dilengkapi dengan narasi Tholkhah (2013). SMA Muhammadiyah Kupang menjadi studi kasus betapa lembaga pendidikan didirikan mengacu kepada spirit keislaman tetapi 
tidak membatasi penyebaran keilmuan untuk warga masyarakat muslim saja. Dalam kaitan dengan umat lain Muhammadiyah tidak hanya berpegang pada prinsip fastabiqul khairat tetapi juga menggunakan prinsip toleransi (Burhani, 2011). Dengan kondisi seperti ini kemudian muncullah istilah Muhammadiyah Kristen, dimana masyarakat Protestan \& Katolik memiliki kesempatan untuk menempuh pendidikan di lembaga yang dikelola Muhammadiyah.

\section{Muhammadiyah Dalam Gerakan Sosial di Minoritas Muslim}

Pelayanan Muhammadiyah dalam aktivitas sosial mengadopsi semangat masyarakat Kristen yang juga tidak membedakan identitas keagamaan (Latief, 2013). Dengan demikian, sebagai gerakan sosial maka tidak membedakan pilihan keagamaan. Maka, sekolah-sekolah Muhammadiyah dijadikan sebagai gerakan sosial. Sebagai gerakan dakwah juga, Muhammadiyah tidak hanya fokus pada soal ibadah semata. Lembaga pendidikan dijadikan sebagai sarana dakwah (Tahang, Wekke \& Fatimah, 2019). Bahkan juga turut berperan dalam perdamaian (Danius, 2012). Untuk itu, organisasi Muhammadiyah secara lokal akan berperan sesuai dengan keadaan lingkungan masing-masing. Sepanjang sejalan dengan misi organisasi secara nasional. Ini dapat diegaskan bahwa Muhammadiyah secara lokal memiliki agenda organisasi sebagai respon dari kondisi wilayah. Sementara secara nasional, ada agenda khusus yang terkai dengan keperluan organisasi.

Sejak awal keberadaan Muhammadiyah memang dimaksudkan sebagai lembaga dakwah yang fokus pada penguatan kapasitas muslim (Barulazi, Wekke \& Rais, 2019). Termasuk berusaha untuk melaksanakan program yang terkait dengan dakwah (Wekke, Barulazi, Rais, \& Idris, 2019). Pendirian lembaga pendidikan mulai dari taman bermain sampai pada perguruan tinggi sebagai amal usaha untuk menjalankan misi organisasi. Sementara itu di Papua Barat (Wekke, Arif, Zubair \& Wardi, 2019), Muhammadiyah membuka diri terhadap pelayanan sosial secara eksternal. Hanya saja, untuk keperluan internal umat Islam juga tetap melakukan penguatan kapasitas (Wahyuddin, Kasan \& Wekke, 2018).

Burhani (2010) mengemukakan bahwa awalnya sebagai gerakan keagamaan, secara kultural Muhammadiyah di Jawa. Namun perkembangan berikutnya justru berayun ke tendeksi puritan (Burhani, 2006). Muhammadiyah akhirnya berkembang tidak lagi hanya di Jawa namun juga menjangkau seluruh wilayah Indonesia. Sehingga terdapat perjumpaan dengan masyarakat lain yang berbeda keyakinan keagamaan. Pada posisi ini Muhammadiyah justru tidak esklusif, justru mengembangkan sikap yang inklusif dan menerima keberadaan masyarakat yang berbeda. Bahkan juga tidak menutup diri untuk bersama-sama dalam aktivitas pendidikan. 


\section{Penutup}

Artikel ini sebagai catatan semasa membaca buku Islamologi dimana digunakan istilah Kristen Muhammadiyah berawal dari publikasi Mu'ti \& Haq sebagai hasil penelitian di tiga lokasi sekolah Muhammadiyah. Selanjutnya, tulisan Hanggawali memperkaya data yang sudah ada. Bahkan, ini sebuah penelitian yang memiliki kekhasan tersendiri dimana ditulis langsung oleh orang Kristen.

\section{Daftar Pustaka}

Barulazi, B., Wekke, I. S., \& Rais, M. (2019, June 13). Gerakan Dakwah Muhammadiyah di Kota Sorong. https://doi.org/10.31227/osf.io/hycdg.

Burhani, A. N. (2006). The ideological shift of Muhammadiyah from cultural into puritanical tendency in 1930s. Jurnal Masyarakat dan Budaya, 8(1), 1-22.

Burhani, A. N. (2010). Muhammadiyah Jawa. Al--Wasat Publishing House.

Burhani, A. N. (2011). Lakum dīnukum wa-liya dīnī: the Muhammadiyah's stance towards interfaith relations. Islam and Christian-Muslim Relations, 22(3), 329-342.

Danius, E. E. (2012). Hubungan Kristen-Islam pasca konflik di Tobelo Halmahera Utara. Journal Uniera, 1(1).

Hanggawali, D. (2019). Orang Kristen Muhammadiyah. Dalam Tambunan, E., \& Ainuri, A. F. Y. (2019). Islamologi. Banten: Arash Publisher.

Latief, H. (2013). Agama dan Pelayanan Sosial; Interpretasi dan Aksi Filantropi dalam Tradisi Muslim dan Kristen di Indonesia. Jurnal Religi, 9(2), 174-189.

Mu'ti, A., \& Haq, F. R. U. (2009). Kristen Muhammadiyah: konvergensi Muslim dan Kristen dalam pendidikan. Al-Wasat Publishing House.

Tahang, H., Wekke, I. S., \& Fatimah, F. (2019, June 13). Dakwah Muhammadiyah Melalui Lembaga Pendidikan. https://doi.org/10.31227/osf.io/scjnq.

Tambunan, E., \& Ainuri, A. F. Y. (2019). Islamologi. Banten: Arash Publisher.

Tholkhah, I. (2013). Pendidikan Toleransi Keagamaan: Studi Kasus SMA Muhammadiyah Kupang Nusa Tenggara Timur. EDUKASI: Jurnal Penelitian Pendidikan Agama dan Keagamaan, 11(2).

Wahyuddin, W., Kasan, W., \& Wekke, I. S. (2018). Pembinaan Aqidah Di Panti Asuhan Minoritas Muslim. International Postgraduate Research Conference. Institut Agama Islam Negeri (IAIN) Manado, 12-13 November 2016. https://doi.org/10.31227/osf.io/j5bq4.

Wekke, I. S., Arif, B., Zubair, A., \& Wardi, M. (2019). The Role of Muhammadiyah Institution Towards Muslim Minority in West Papua. Jurnal Ilmiah Peuradeun, 7(1), 21-42.

Wekke, I. S., Barulazi, B., Rais, M., \& Idris, I. (2019, June 13). Akselerasi Gerakan Dakwah Muhammadiyah di Wilayah Minoritas Muslim Papua Barat. https://doi.org/10.31227/osf.io/7n9bj. Tadarus Pemikiran Jaringan Intelektual Muda Muhammadiyah (JIMM), Universitas Muhammadiyah Malang, 23-24 Mei 2018. 